\title{
Leaf midrib outline as a diagnostic character for taxonomy in Anthurium section Urospadix subsection Flavescentiviridia (Araceae)
}

\begin{abstract}
André Mantovani ${ }^{1,2}$, Thaís Estefani Pereira ${ }^{1}$ and Marcus A. Nadruz Coelho ${ }^{1}$
Received: 01.11.2007; accepted: 23.04.2009

ABSTRACT - (Leaf midrib outline as a diagnostic character for taxonomy in Anthurium section Urospadix subsection Flavescentiviridia (Araceae)). The external morphology of the midrib of the leaf lamina is used as a diagnostic character for the taxonomy of species of Anthurium subsection Flavescentiviridia (section Urospadix) (Araceae). Our aims in this study are: characterize using morphological analysis the variation of the outline of the midrib along the leaf lamina using 22 of the 35 species of the subsection; evaluate the potential of this variation as a diagnostic tool for taxonomy. For each species, the leaf lamina was divided into three pieces of identical length. The median point of each region was transversely sectioned and its outline drawn with the aid of a camera lucida and microscope. Five distinct types of outlines were classified using current terminology. Considering the difficulty of diagnosing many of the species, this character could be useful for the taxonomy of this subsection.
\end{abstract}

Key words: leaf, monocots, morphology, species diagnosis

RESUMO - (Morfologia da nervura central da lâmina foliar como caráter diagnóstico para taxonomia de Anthurium subseção Flavescentiviridia (Araceae)). A morfologia da nervura central da lâmina foliar é usada como caráter diagnóstico para separar espécies do gênero of Anthurium subseção Flavescentiviridia (seção Urospadix) (Araceae). Os objetivos deste estudo são: através de análise morfológica, caracterizar a variação da forma da nervura central ao longo da lâmina foliar usando 22 das 35 espécies da subseção; avaliar o uso potencial desta variação como ferramenta para diagnose taxonômica de espécies de Anthurium da subseção Flavescentiviridia. Para cada espécie, a lâmina foliar foi dividida em três regiões de igual comprimento. A nervura central no ponto médio de cada região foi cortada transversalmente e sua forma delineada com auxílio de câmara clara. Os diferentes tipos de nervura central foram classificados utilizando-se terminologia corrente. Considerando-se a complexidade taxonômica do gênero, este caráter pode ser útil para taxonomia desta subseção.

Palavras-chave: diagnose de espécies, folha, morfologia, monocotiledôneas

\section{Introduction}

The Araceae comprises 2,823 species in 109 genera (Gonçalves 2005). Anthurium, described by Schott in 1829 , is the largest genus in the family, with approximately 1,000 species (Coelho 2006). In 1878, Engler divided the genus into 18 sections, and in 1898 the same author defined six subsections for section Urospadix, one of which is Flavescentiviridia, that actually presents 34 of its 35 species occurring in southeastern Brazil (Coelho 2004).

Engler (1905) and Schott (1860) described and distinguished aroid species using the external morphology of the midrib at the central region of the leaf lamina but not indicating the leaf region (basal, median or distal part) assessed. Anatomical studies have revealed that this character can vary along the leaf lamina (e.g. Leo et al. 1997 in Rubiaceae).
The outline format has been evaluated for species diagnosis in plant families other than Araceae, commonly using petiole and scape cross sections (Ferraz \& Costa 1985, Scatena \& Giulietti 1999, Metcalfe \& Chalk 1950, 1979, Hussin \& Sani 1998, Godoy \& Costa 2003). For the Araceae, some previous studies examined the possible application of the leaf midrib outline as a diagnostic tool for aroid taxonomy (Croat \& Bunting 1979, Mayo 1986, Keating 2002).

Anthurium is, morphologically, one of the most diverse genera of Araceae at the species level. This makes it complex and difficult taxonomically (Coelho $\&$ Mayo 2007). To the best of our knowledge, there is no published study which evaluates the variation of the midrib outline along the leaf lamina as a diagnostic character for species of Anthurium section Urospadix subsection Flavescentiviridia. Our intentions here are:

1. Instituto de Pesquisa Jardim Botânico do Rio de Janeiro, Rua Pacheco Leão 915, 22460-030, Rio de Janeiro, RJ, Brasil

2. Corresponding author: andre@jbrj.gov.br 
through morphological analysis, record the variation in outline along the leaf lamina of the midrib in 22 species of Anthurium section Urospadix subsection Flavescentiviridia; and evaluate the potential use of this variation for diagnostic purposes in these species.

\section{Material and methods}

Morphological analyses were performed using cultivated and herbarium specimens. Individuals from Anthurium section Urospadix, subsection Flavescentiviridia were collected in different locations in Brazil and cultivated under identical glasshouse conditions in the Rio de Janeiro Botanical Garden (RJBG), Brazil. Subsection Flavescentiviridia has 35 species, 22 of them cultivated in the RJBG (table 1). Only these cultivated materials were studied. The other species not studied here were A. bellum Schott, $A$. boudetii Nadruz, A. bocainense Catharino \& Nadruz,

Table 1. Diagrams representing the outline types of the midribs found along the leaf lamina in 22 species of Anthurium section Urospadix subsection Flavescentiviridia. A general model is shown, indicating the junction of intercostal regions (IR) and midrib (M): angular not continuous (arrow) or not angular, continuous (circle). For each outline type, two examples representing possible variations along the same type of an outline are shown.

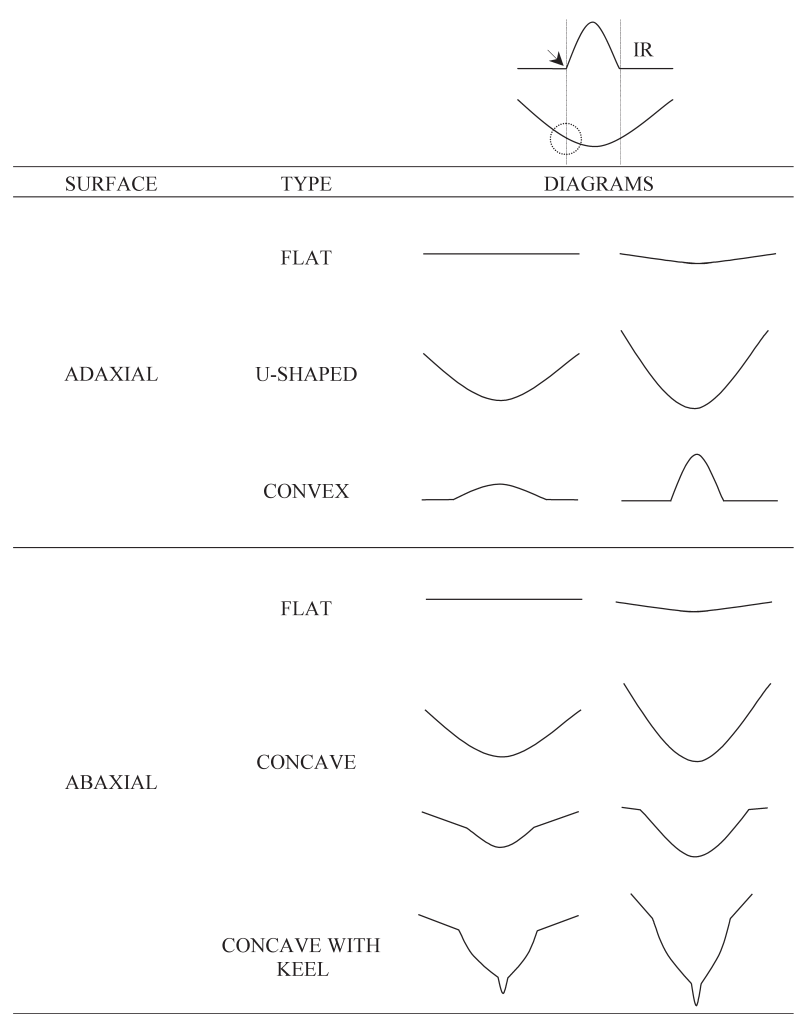

A. fontellanus Nadruz \& Leoni, A. fragae Nadruz, $A$. gomesianum Nadruz, A. jureianum Catharino \& Olaio, A. langsdorffii Schott, A. miquelianum K. Koch, $A$. navicularis Catharino \& Nadruz, A. pilonense Reitz, A. simonii Nadruz, A. unense Nadruz \& Catharino. Nomenclature followed Sakuragui \& Mayo (1999) and Coelho $(2004,2006)$. All the studied species were analyzed using one sample obtained from fresh leaf collected in the field. Except for A. regnellianum Engl. and A. victorii Nadruz \& Catharino which sample were obtained only from cultivated material, for 20 species (table 1), one or two other specimens were also analyzed using preserved leaves collected from herbarium specimens.

For each cultivated species, mature expanded leaves were collected. Fresh leaves were collected in the field, preserved in plastic bags, and brought to the laboratory. Preserved leaves from herbarium specimens were previously hydrated for $48 \mathrm{hs}$ before fixation (Kraus \& Arduin 1997). Fresh and preserved leaves were fixed in FAA 70. For each species, leaf laminas were dissected from the petioles with a razor blade, measured with a rule and divided into proximal, median and distal pieces of identical length. For each piece, the mid-length at the midrib was determined. At this point, the entire midrib plus intercostal regions $(0.5 \mathrm{~cm}$ width $\times 0.4 \mathrm{~cm}$ length each $)$ was sectioned and separated into two pieces $(0.5 \mathrm{~cm}$ width $\times 0.2 \mathrm{~cm}$ length). One piece was cross sectioned by hand with a razor blade, treated using standard techniques and stained with Safrablau (Johansen 1940). The other one was fixed in solution of glutaraldehyde $4 \%$ and formaldehyde 1\% (McDowell 1978) in a sodium phosphate buffer $0.1 \mathrm{M}, \mathrm{pH} 7.2$, dehydrated in ethylic series, included in hydroxyethylmethacrylate (Gerrits $\&$ Smid 1983), sectioned at a 2-4 $\mu$ m thickness using a Spencer microtome, and stained with Toluidine Blue O (O’Brien \& McCully 1981). Photomicrographs were taken with an Olympus BX-50 light microscope and a Coolsnap digital camera. The outline of each section, including the entire midrib and both intercostal regions, was drawn at $40 \times$ magnification with the aid of a camera lucida.

Midrib outline was classified using current terminology described in Croat \& Bunting (1979). These authors, proposing a standardization of Anthurium descriptions, classified midrib outlines as convex, concave, flat, V-shaped, U-shaped and omega-shaped.

In order to evaluate the potential application of the outline of leaf midribs in Anthurium for taxonomy a morphological key was constructed. 


\section{Results}

For the majority of the species studied, the midrib outline varied along the leaf lamina (figures 1 - 23). This variation was different on the adaxial and abaxial surfaces. Only the types V-shaped and omega-shaped were not observed. However midribs with a keel were detected in some of the species studied. The outlines found were (tables 1,2):

a) flat - midrib not prominent and at the same horizontal level or slightly down curved below of the intercostal regions. Very little upright folding. It occurs on both adaxial (figure 23) and abaxial surfaces (figure 28).

b) U-shaped - midrib plus both intercostals continuous but clearly folded upright. It occurs on the adaxial surface only (figure 24).

c) convex - midrib convexly prominent. Prominence varies from rounded to triangular (figures $25,26,28)$. Junction of both intercostal regions and midrib is usually angular, not continuous, but sometimes smoothly curved. It occurs only on the adaxial surface.

d) concave - midrib prominent. Prominence varies from U-shaped to triangular, from a slightly to a marked manner. It occurs only on the abaxial surface (figures 24, 25, 26).

e) concave with keel - identical to the concave type (midrib concavely prominent), but with cortical tissue projection toward the outside of midrib, constituting a keel (Figure 28). Junction of both intercostal regions and midrib is acute, not continuous. It occurs only on the abaxial surface.

The distribution of the types of midrib outline along the leaf lamina of the species examined is shown in tables 1 and 2. There were no differences in relation to the pattern of distribution of the midrib types found on cultivated and herbarium dry materials. Attention should be dedicated when analyzing the midrib outline at the distal region of Anthurium leaves. The oultine type found at the mid-length at this region could be distinct from the one found more forward near to the leaf apex. For example, the adaxial surface of the midrib of A. luschnatianum is smoothly convex at the mid-length portion of the distal region (figure 15) but flat at the apex (figure 23).

On the majority of the concave midribs at abaxial surface, the junction of both intercostal regions and midrib was angular, not continuous (table 2). However, sometimes, this junction between intercoastal region and midrib was continuous, constituting an U-shaped type at the abaxial surface, where midrib plus both intercostal regions were clearly folded upright. Considering that the distinction between both types (concave and U-shaped) could be arbitrary, both types were merged in the concave one.

The potential application of the trait "variation of the midrib outline" for the diagnosis of Anthurium species was evaluated here. A taxonomic key was constructed and the 22 species studied could be separated into six distinct groups. Sixteen species presented the convex type at adaxial surface and the concave type at the abaxial surface along all the three portions of its leaves. Only five species presented some variation along the three leaf portions, and only at the adaxial surface. On A. bragae, A. hoehnei and A. longicuspidatum the adaxial surface varied from the convex type at the proximal region to the U-type at the distal region. Variation from the flat type at proximal region to the convex type at the distal region occurred on A. luschnathianum. Only A. harrisii and A. marense presented the concave type with keel until the median portion of the midrib at the abaxial surface, while on A. intermedium and A. urvilleanum the concave with keel type was restricted to the proximal region of the midrib at the abaxial surface. The species $A$. regnelianum was the only one presenting a flat type of the midrib along the entire adaxial surface. This result show a potential application of this leaf character to characterize group of species of Anthurium section Urospadix subsection Flavescentiviridia. 


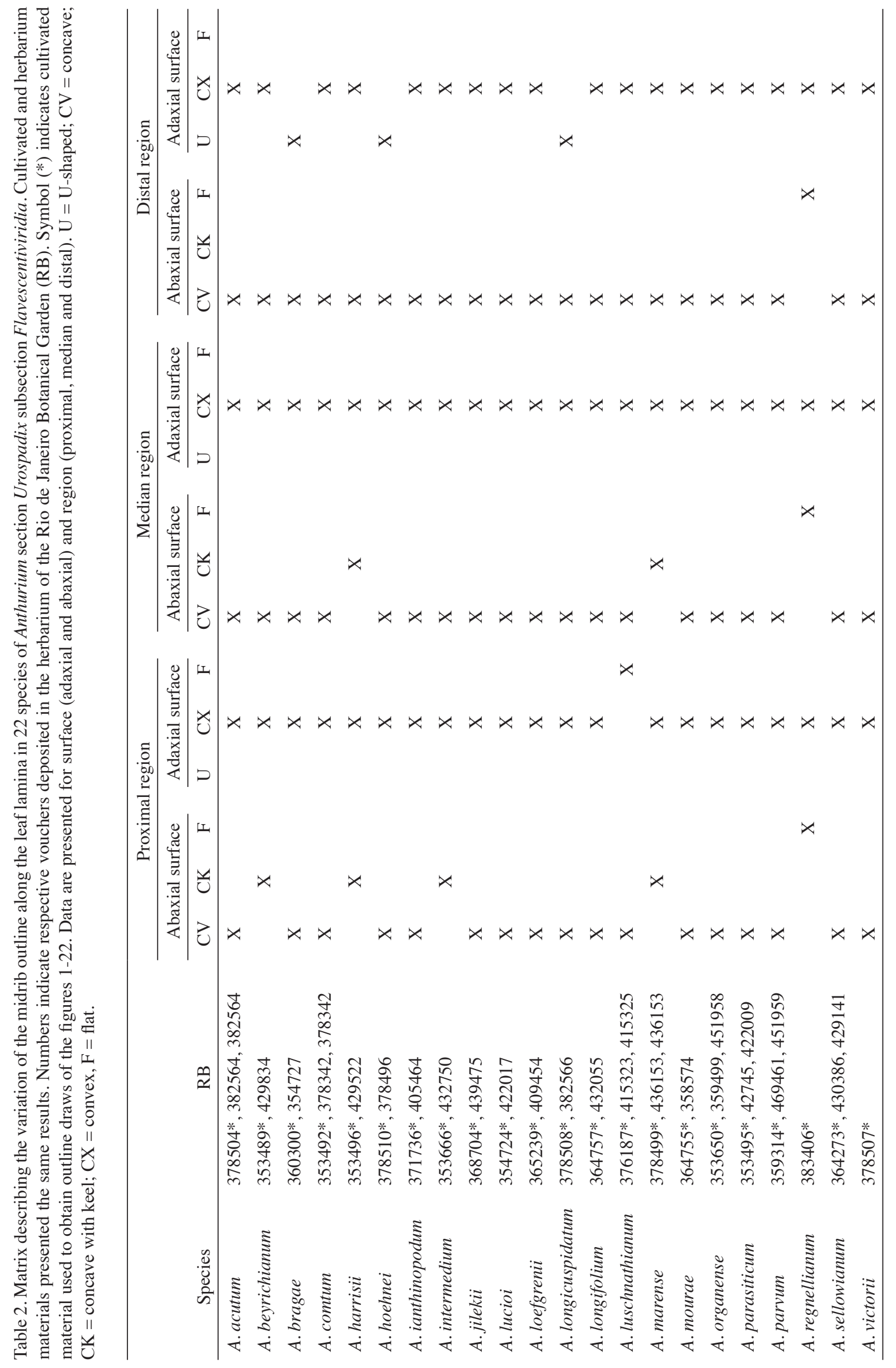




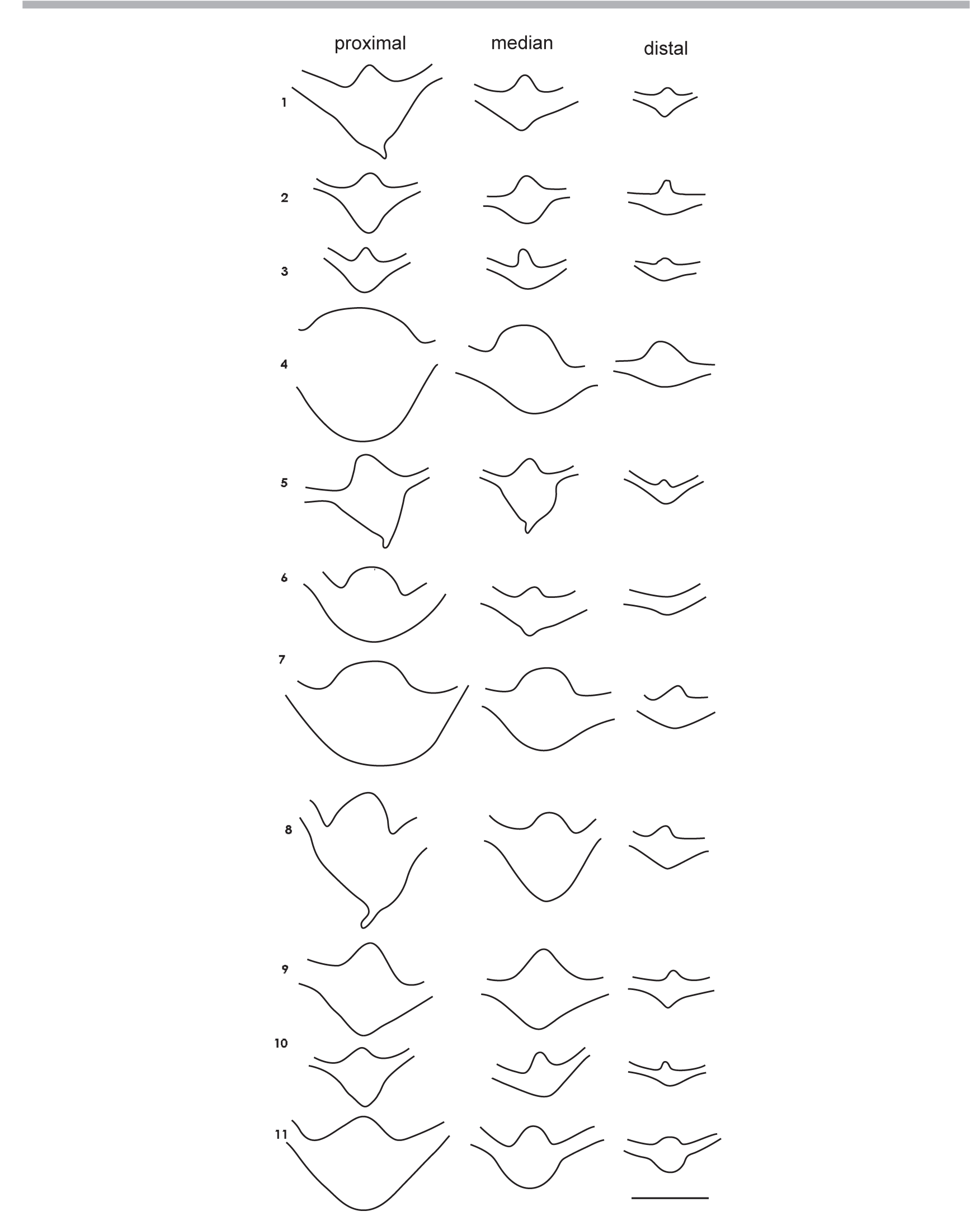

Figures 1-11. Midrib outlines from species of Anthurium section Urospadix subsection Flavescentiviridia. Each line represents one species and its respective midrib cross sectioned in the proximal, median and distal regions. 1. A. acutum. 2. A. beyrichianum. 3. A. bragae. 4. A. comtum. 5. A. victorii. 6. A. harrisii. 7. A. hoehnei. 8. A. ianthinopodum. 9. A. intermedium. 10. A. jilekii. 11. A. lucioi. Bar = 7600um. 
proximal

12

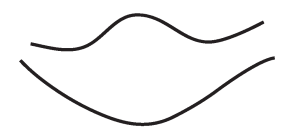

13

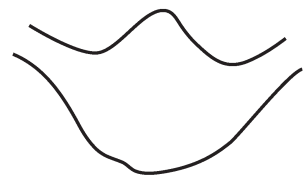

14

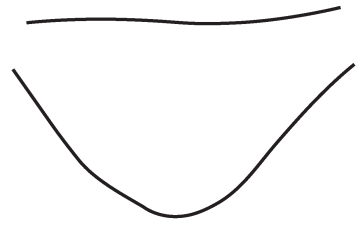

15

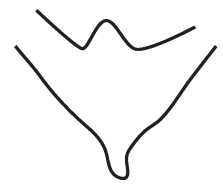

16
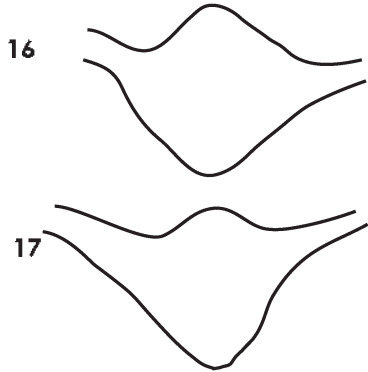

18

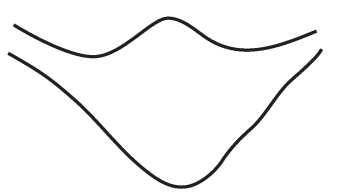

19

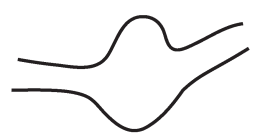

20

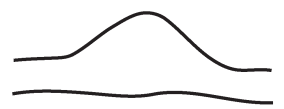

21

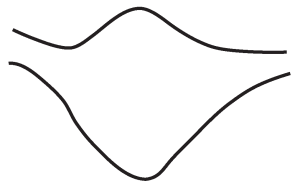

22

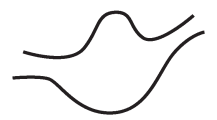

median

distal
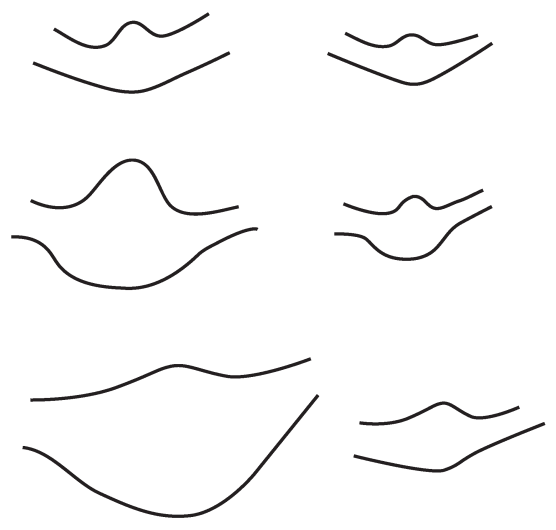

$v^{2}$
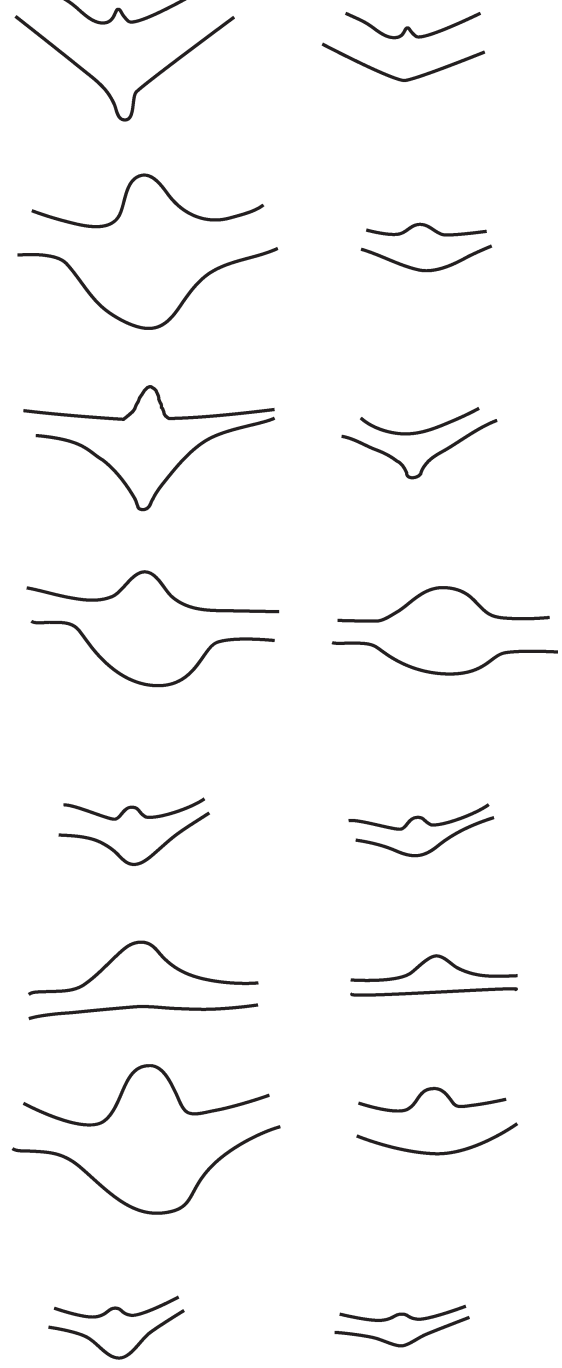

Figures 12-22. Midrib outlines from species of Anthurium section Urospadix subsection Flavescentiviridia. Each line represents one species and its respective midrib cross sectioned in the proximal, median and distal regions. 12. A. loefgrenii. 13. A. longicuspidatum. 14. A. longifolium. 15. A. luschnathianum. 16. A. marense. 17. A. mourae. 18. A. organense. 19. A. parasiticum. 20. A. parvum. 21. A. regnellianum. 22. A. sellowianum. 

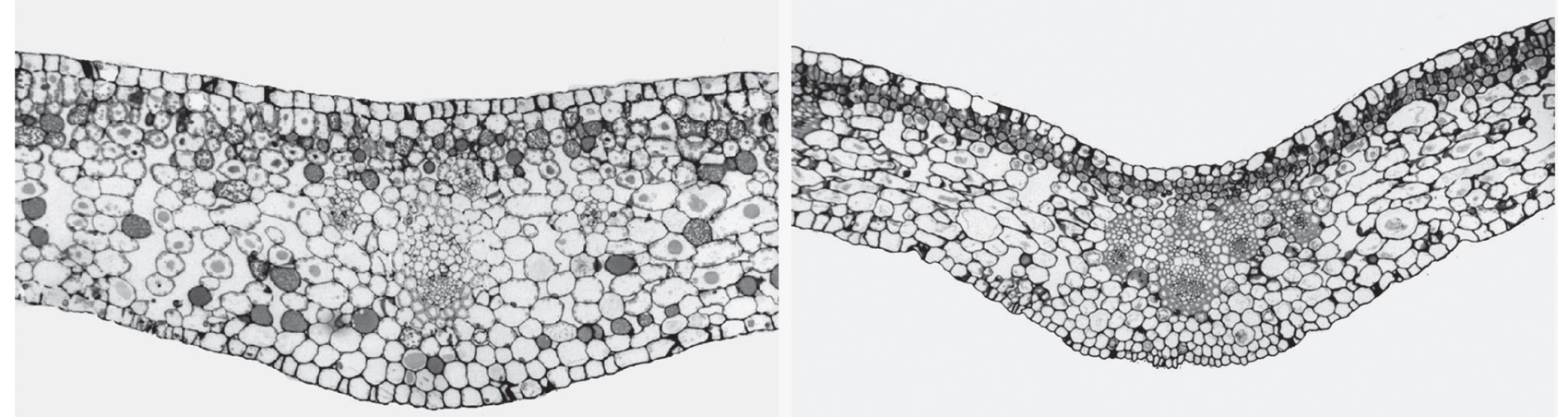

23

24
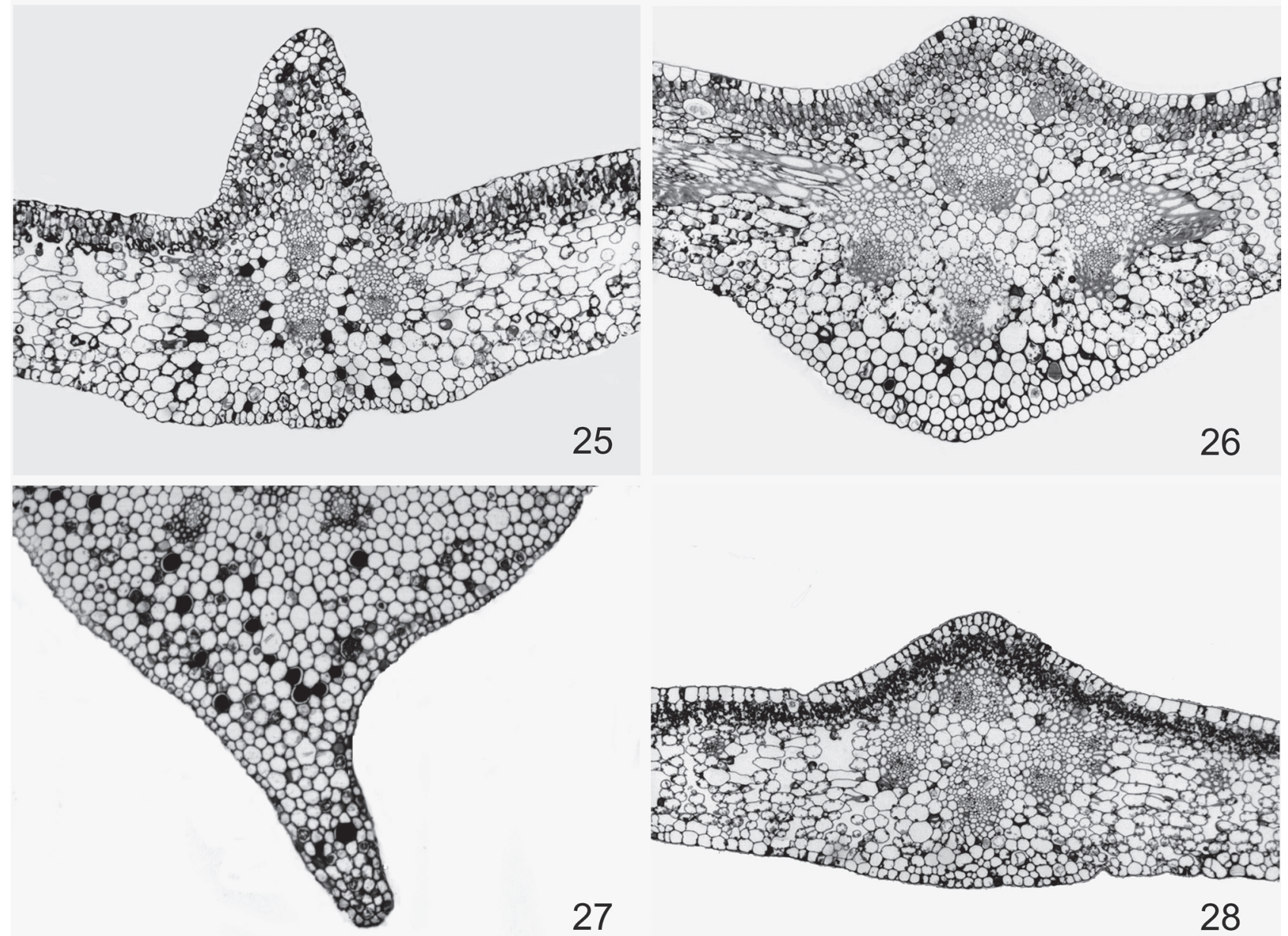

Figures 23-28. Cross sections of leaf midribs of Anthurium species section Urospadix subsection Flavescentiviridia. 23. Adaxial surface flat, abaxial surface concave in the leaf apex of A. luschnathianum. 24. Adaxial surface U-shaped, abaxial surface concave in A. longicuspidatum (distal region). 25. Adaxial surface convex, abaxial surface concave in A. beyrichianum (distal region). 26. Adaxial surface convex, abaxial surface concave in A. longifolium (distal region). 27. Abaxial surface concave with keel in A. harrisii (median region). 28. Adaxial surface convex, abaxial surface flat in A. regnellianum (distal region). Bar $=350 \mu \mathrm{m}$. 
Taxonomic key based on the outline of the adaxial and abaxial midrib surfaces along the leaf lamina in 23 species of Anthurium section Urospadix subsection Flavescentiviridia

1. Abaxial surface proximal region flat A. regnellianum

1. Abaxial surface proximal region concave or concave with keel

2. Abaxial surface proximal region concave with keel

3. Abaxial surface median region concave with keel A. harrisii, A. marense

3. Abaxial surface median region concave A. urvilleanum, A. intermedium

2. Abaxial surface proximal region concave

4. Adaxial surface proximal region flat A. luschnathianum

4. Adaxial surface proximal region convex

5. Adaxial surface distal region concave A. bragae, A. hoehnei, A. longicuspidatum

5. Adaxial surface distal region convex A. acutum, A. comtum, A. ianthinopodum, A. jilekii, A. lucioi, A. loefgrenii, A. longifolium, A. mourae, A. organense, A. parasiticum, A. parvum, A. sellowianum, A. victorii

\section{Discussion}

Vegetative characteristics such as habit, phyllotaxy and leaf venation are important for description and identification of plant species. However the outline of plant organs in cross section is relatively less used for species diagnosis (Judd et al. 1999). Examples are the works of Nyffeler \& Eggli (2000) on the shoot and Wege (2001) on the scape. In relation to the leaf, both petiole and leaf lamina outline in cross section have already been applied to the diagnosis of plant species (Metcalfe \& Chalk 1950, 1979, Leo et al. 1997, Sajo et al. 1995).

However fewer references were found about the use of midrib outlines for species diagnosis (Mantovani \& Pereira 2005). Bačić et al. (1992) compared the midribs of three species of Arbutus (Ericaceae) and Woltz et al. (1987) described the midrib outline prominence or concavity for 112 of the 184 species of Podocarpineae. Both authors concluded that the midrib outline is a useful character for taxonomy.

In Araceae, Engler (1905), Schott (1893), Croat (1997), Keating (2002), and others have reported the usefulness of the midrib outline for the diagnosis of species. Keating (2002) described the midrib outline of leaf lamina in Philodendron (Araceae) that varies from ridged to concave on the adaxial surface but is less variable on the abaxial surface, varying from slight to highly convex. Our results in Anthurium detected five distinct types of midrib outline, but only three types occurred on the adaxial surface, and four on the abaxial surface. The same author stated that while highly variable, the midrib outline of the leaf lamina in Philodendron could be useful for the taxonomy of the genus. Although not testing this hypothesis for Anthurium, Keating (2002) reported the possible application of the midrib outline for the diagnosis of the species in this genus.

This application was tested here for several Anthurium species from the section Urospadix subsection Flavescentiviridia. The variation of the midrib outline along the leaf lamina was useful for the diagnosis of the studied species, as exemplified by some taxonomical complexes in Flavescentiviridia. The species Anthurium harrisii, A. intermedium, A. jilekii, A. sellowianum and A. urvilleanum present similar morphological and reproductive characters that limit species diagnosis and separation. The shape of their leaves, widely used for the taxonomy of Anthurium, are highly overlapped. The same applies to the morphology of their inflorescences. But the differences in the outline of their midribs separate these five species into three distinct groups. In A. hoehnei and A. marense, in addition to the plasticity of the leaf blade, secondary and tertiary ribs provide a bulate aspect for the leaf, making species delimitation confused, but midrib, in this case, confirmed the distinction of these species. Another example is represented by the species $A$. luschanthianum and A. parasiticum, which in the past were considered synonymous because of their very similar morphological and reproductive characters, nevertheless, the difference between the outline of their mibrids reported here, reinforce the taxonomical distinction of both species.

Considering that Anthurium probably has a thousand species, some of them morphologically similar in the vegetative state, we suggest that the midrib outline in cross-section, along the leaf lamina, has high potential for the diagnosis and taxonomy of species of Anthurium section Urospadix subsection Flavescentiviridia. 


\section{Acknowledgments}

The authors are indebted to Dr. Douglas Daly for revision of the manuscript. The first author thanks FAPERJ for financial support. The second author was sponsored by the Conselho Nacional de Pesquisa e Desenvolvimento (PIBIC/CNPq).

\section{Literature cited}

Bačić, T., Lawrence, T.J. \& Cutler, D.F. 1992. Leaf anatomy of an Arbutus taxon from Yugoslavia. Kew Bulletin 47: 535-543.

Coelho, M.N. \& Mayo, S.J. 2007. Typifications of names of Brazilian taxa of Anthurium sect. Urospadix (Araceae). Taxon 56: 211-225.

Coelho, M.A.N. 2004. Taxonomia e biogeografia das espécies do gênero Anthurium (Araceae) seção Urospadix subseção Flavescentiviridia. Tese de Doutorado, Universidade Federal do Rio Grande do Sul, Porto Alegre.

Coelho, M.A.N. 2006. New species of Anthurium (Araceae) for Brazil. Aroideana 29: 91-103.

Croat, T.B. 1997. A revision of Philodendron subgenus Philodendron (Araceae) for Mexico and Central America. Annals of the Missouri Botanical Garden 84: 311-704.

Croat, T.B. \& Bunting, G.S. 1979. Standardization of Anthurium descriptions. Aroideana 2: 15-25.

Engler, A. 1905. Pothoideae. In: A. Engler (ed.). Das Pflanzenreich IV. Ed., 23B (Heft 21). Engelmann, Leipzig, pp. 133-174.

Ferraz,C.L.A.\& Costa, C.G. 1985. Paullinia carpopodea Camb. (Sapindaceae). Anatomia foliar. Rodriguesia 37: 79-90.

Gerrits, P.O. \& Smid, L. 1983. A new, less toxic polymerization system for the embedding of soft tissues in glycol methacrylate and subsequent preparing of serial sections. Journal of Microscopy 132: 81- 85.

Godoy, Z.R. \& Costa, C.G. 2003. Anatomia foliar de quatro espécies do gênero Cattleya Lindl. (Orchidaceae) do Planalto Central Brasileiro. Acta Botanica Brasílica 17: 101-118.

Gonçalves,E.G. 2005. Two new Andean genera for the tribe Spathicarpeae (Araceae). Willdenowia 35: 319-326.

Hussin, K.H. \& Sani, Z.M. 1998. Comparative leaf anatomical studies of some Sterculia L. species (Sterculiaceae). Botanical Journal of the Linnean Society 127: 159-174.

Johansen, D.A. 1940. Plant microtechnique. Mc-Graw. Hill, New York.

Judd, S.W., Campbell, C.S., Kellogg, A.E. \& Stevens, F.P. 1999. Plant systematics: a phylogenetic approach. Sinauer Associates, Sunderland.
Keating,R.C. 2002.Acoraceae and Araceae. In: M. Gregory $\&$ D.F. Cutler (eds.). Anatomy of the monocotyledons, vol. 9. Oxford University Press, New York, pp. 1-327.

Kraus, J. E. \& Arduin, M. 1997. Manual básico de métodos em morfologia vegetal. Edur, Rio de Janeiro.

Leo, R.T.R., Mantovani, A. \& Vieira, R.C. 1997. Anatomia foliar de Rudgea ovalis Müll. Arg. e Rudgea tinguana Müll. Arg. (Rubiaceae). Leandra 12: 33-44.

Mantovani, A. \& Pereira, T.E. 2005. Comparative anatomy of leaf and spathe of nine species of Anthurium (section Urospadix; sub-section Flavescentiviridia) (Araceae) and their diagnostic potential for taxonomy. Rodriguesia 56: 146-160.

Mayo, S.J. 1986. Systematics of Philodendron Schott (Araceae) with special reference to inflorescence characters. PhD Thesis, University of Reading, Reading.

Mcdowell E.M.1978. Fixation and processing.In: B.F.Trump \& R.T. Jones (eds.). Diagnostic electron microscopy. John Wiley \& Sons, New York, pp. 113-169.

Metcalfe, C.R. \& Chalk, L. 1950. Anatomy of the Dicotyledons, 1 ed. Oxford University Press, New York.

Metcalfe, C.R. \& Chalk, L. 1979. Anatomy of the Dicotyledons, 2 ed. Oxford University Press, New York.

Nyffeler, R. \& Eggli, U. 2000. Similarity is only skin-deep: the use of comparative plant anatomy as illustrated by a study of columnar cacti from Chile (Eulychnia and Echinopsis, Cactaceae). Botanica Helvetica 110: 1-10.

O'Brien, T.P. \& McCully, M.E. 1981. The study of plants structure: principles and selected methods. Termarcarphi Pty, Melbourne.

Sajo, M.G., Wanderley, M.G.L.\& Carvalho,L.M. 1995. Caracterização anatômica foliar para 14 espécies de Xyris L. (Xyridaceae) da Serra do Cipó, MG, Brasil. Acta Botanica Brasilica 9: 101-114.

Sakuragui, C.M. \& Mayo, S.J. 1999. A new species of Anthurium (Araceae) from south-eastern Brazil. Feddes Repertorium 110: 535-539.

Scatena, V.L. \& Giulietti, A.M. 1999. Morfo-anatomia de espécies de Blastocaulon Ruhland (Eriocaulaceae). Acta Botanica Brasilica 13: 29-41.

Schott, H.W. 1860. Prodromus Systematis Aroidearum. Typis Congregationis Mechitharistichae. Horto Schoenbrunnensi, Vienna.

Wege, J.A.2001. Scape anatomy in Stylidium (Stylidiaceae). Kew Bulletin 56: 955-963.

Woltz,P.H., Gajardo, R.\& Ferreira,A.G. 1987.Anatomia comparada das folhas e evolução das Podocarpineae. Acta Botanica Brasilica 1: 77-99. 